\title{
Natalia Kowalska
}

Uniwersytet Łódzki

ORCID: 0000-0002-9726-8227

\section{Eksperyment radiowy jako gatunek}

\begin{abstract}
Streszczenie
Celem tego artykułu jest uyjaśnienie istoty eksperymentu audialnego, określenie jego związku z innymi gatunkami radiouymi, uspółczesną sztuką audialną oraz sformułowanie prau rządzących eksperymentem fonicznym i jego wyznaczników gatunkowych. W badaniu eksperymentu posłużę się opracowaniami literaturoznawczymi, które będą stanowić dla mnie punkt odniesienia teoretycznego. Ze uzględu na próbę określenia eksperymentu jako gatunku, metodą, którą uybrałam, jest radioznawcze podejście genologiczne z wykorzystaniem wzorca gatunkowego. Eksperyment radiouy może być traktowany jako autonomiczny, mimo wewnętrznego zróżnicowania, realizacje uykazują pewne cechy uspólne. Formy eksperymentalne znajdowały się na marginesie badań radioznawczych, mimo że miały duży upływ na rozwój i oceny kształt klasycznych gatunków audialnych. Artykuł omawia również kwestie struktury, estetyki i antyestetyki radiouych dzieł eksperymentalnych.
\end{abstract}

Słowa kluczowe: eksperyment, gatunki radiowe, sztuka audialna.

\section{Experiment as a radio genre}

\begin{abstract}
The main aim of this article is to describe the nature of radio experiment, its genre pattern and relations with modern radio art and to define the ruling principles of this form. Literature Theory, journalism genres (both press and radio), genre's pattern theory will be the referring points for this study. Radio experiment can be understood as an autonomic radio genre, even though it is a very complex and internally diverse form. Experimental forms have been always outside of the mainstream radio research although they had an influence on the development of radio genres in the past and their contemporary form. This article describes the matters of structure, aesthetics and non-aesthetics in the field of audio experiment.
\end{abstract}

Keywords: experiment, radio genres, radio art.

\section{Wprowadzenie}

Eksperymentalne formy radiowe, jak uszystkie pozanormatywne formy artystyczne, doczekały się wielu realizacji i niewspółmiernie mało opisów teoretycznych. Eksperymenty u sztuce radiowej są nazywane, w zależności od kontekstu i miejsca emisji, audialnymi, fonicznymi, dźwiękouymi lub radiouymi. Pojęcia te traktować będę 
synonimicznie, niezależnie od tego, czy dana forma została wyemitowana w stacji radiowej, stworzona w ramach kompilacji nagranej na konkretny nośnik (na przykład na taśmę magnetofonową), czy poustała na potrzeby strony internetowej, podcastu. Za wyróżniki omawianej formy uznaję jej konstrukcję, treść czy poruszaną tematykę, nie zaś sposób upublicznienia. Eksperymenty radiowe, chociaż wewnętrzne zróżnicowane, wykazują zespół cech uspólnych, które chciałabym przybliżyć i opisać u kontekście wzorca gatunkowego.

Celem tego artykułu jest wyjaśnienie istoty eksperymentu audialnego, określenie jego związku z innymi gatunkami radiowymi, współczesną sztuką audialną oraz sformułowanie praw rządzących eksperymentem fonicznym i jego wyznaczników gatunkowych. Eksperyment radiowy uważam za formę róunie istotną, co znane już genologii radiowej formy, zarówno dokumentalne, jak i artystyczne. Odwołania do eksperymentów są obecne w badaniach radioznawczych, a metody czy praktyki twórcze bywają określane jako eksperymentalne u odróżnieniu od klasycznych, jednak istota eksperymentu pozostaje niejasna, podobnie jak jego założenia i cele. Nie uszystko bowiem co eksperymentalne jest eksperymentem jako gatunkiem radiowym, czego postaram się dowieść w tym tekście.

Pytania badawcze, jakie sobie stawiam, są związane ze statusem ontologicznym eksperymentu, jego funkcjonowaniem w środowisku artystycznych gatunków radiowych, jego strukturą i funkcją.

W badaniu eksperymentu posłużę się opracowaniami literaturoznawczymi, które stanowić będą dla mnie punkt odniesienia teoretycznego. Ze uzględu na próbę określenia eksperymentu jako gatunku, metodą, którą uybrałam, jest radioznawcze podejście genologiczne. Istotne są dla mnie kwestie związane z wykorzystaniem konkretnych tworzyw dźwiękowych oraz struktura dzieła, do analizy których posłużę się podejściem strukturalistycznym uypracowanym przez Jana Mukařovskú'ego i uybranymi koncepcjami estetycznymi. Za inspirujące uważam również ustalenia Allena S. Weissa i Magz Hall.

Za punkt wyjścia chciałabym przyjąć stanowisko względem eksperymentu na polu sztuk szeroko opracowanych naukowo przez badaczy literatury czy filmu. Brian McHale, Joe Bray i Alison Gibbons we wstępie do Routledge Companion to Experimental Literature o eksperymencie w literaturze piszą: „cecha, którą dzielą wszystkie eksperymenty to stawianie fundamentalnych pytań o naturę i istotę sztuki werbalnej samej w sobie. Czym jest literatura i czym mogłaby być? Jakie są jej funkcje, ograniczenia, możliwości? [...]. To ten rodzaj kwestii, które literatura głóunego nurtu zazwyczaj wypiera” ${ }^{1}$. Autorzy uskazują na autoteliczność dzieł, konkretna realizacja staje się analizą medium, które jest jej nośnikiem. O autoteliczności u filmie Alicja Helman pisze: „celem filmu autotematycznego jest przedstawienie stosunku twórcy do tworzywa, środków wyrazu i filmowanych wydarzeń, co ma decydujący wpłyu na postawę odbiorcy wobec

\footnotetext{
${ }^{1}$ J. Bray, A. Gibbons, B. McHale, Introduction [w:] The Routledge Companionto Experimental Literature, red. J. Bray, A. Gibbons, B. McHale, Routledge, London-New York 2012, s. 1.
} 
dzieła"2. Zorientowanie na refleksje twórcy oraz nowatorskie podejście do tworzywa, z którym autor pracuje, są charakterystyczne również dla eksperymentów audialnych. Autorzy przenoszą swoje działania na nowy poziom wrażliwości, wykorzystują nowe sposoby operowania dźwiękiem, dokonują reinterpretacji dotychczasowych zjawisk obecnych $w$ radiu.

Magz Hall zauważa, że „obecne radiowe prace archeologiczne mogą jedynie patrzeć ustecz na fragmenty historii artystów radiowych, których eksperymenty odpierały populistyczne wymogi przemysłu radiowego i odkrywały granice form" 3 . Prace eksperymentalne poustawały od początku istnienia medium radiouego, można zaryzykować stuierdzenie, że być może to ułaśnie pierusze produkcje radioue sprzyjały eksperymentom, bowiem „kluczowym sprzymierzeńcem w tym dążeniu [do eksperymentu - przyp. N.K.] okazuje się rozwój technologiczny. Fascynacja innowacyjnymi rozwiązaniami technicznymi udzieliła się także artystom, którzy, eksperymentując z nowatorskimi narzędziami, odsłaniali zupełnie nowe obszary obcowania ze światem. Problem pojawił się, gdy nowe technologie stały się synonimem eksperymentu w sztuce - gdy środek zajął miejsce celu. Ich dzisiejsze, masoue wykorzystywanie w dużej mierze zbanalizowało to, co zuykliśmy nazywać praktyką eksperymentalną" . Montaż dźwięku i próba przełożenia języka filmu na awizualną praktykę radiową charakteryzował niemieckich pionierów radiouych, jednym z najbardziej rozpoznawalnych dzieł jest Wochenende Waltera Ruttmanna poustałe u 1930 roku. Kolekcja dźuięków miała symbolizować miejski ruch, bez wyraźnej linii fabularnej przedstawiać słuchaczowi dźwiękoue pejzaże Berlina.

\section{Eksperyment - próba definicji}

Eksperyment na gruncie sztuki jest rozumiany bardzo szeroko, terminem tym posługują się uczeni i praktycy związani z niemal każdym obszarem działań artystycznych: muzyką, literaturą, filmem, sztukami wizualnymi. Niezuykle pojemną definicję eksperymentu proponuje artysta John Cage, kierując swoje rozważania w stronę praktycznego przebiegu procesu eksperymentowania: „słowo eksperyment nie odnosi się do aktyuności, która może podlegać ocenie, którą odbiorcy uznają za sukces lub porażkę, eksperyment to każde działanie, którego rezultat pozostaje nieznany"5. Takie pojmowanie eksperymentu przybliża go do działań naukouych, prób badawczych. Podobnie interpretują zjawisko Magda Roszkouska i Bogna Świątkouska we ustępie do Studia eksperyment. Zbiór tekstów, które przywołują słowa Francisa Bacona

\footnotetext{
2 A. Helman, Autotematyzm [w:] Stownik filmu, red. R. Syska, Krakouskie Wydawnictwo Naukowe, Kraków 2010.

${ }^{3}$ M. Hall, Radio After Radio: Redefining radio art in the light of new media technology through expanded practice, maszynopis pracy doktorskiej, Londyn 2015, s. 26.

${ }^{4}$ M. Roszkouska, B. Świątkouska, Wstęp, Studio Eksperyment. Zbiór tekstów, Fundacja Bęc Zmiana, Warszawa 2013, s. 7-8.

5 J. Cage, cyt. za: M. Roszkouska, B. Świątkouska, Studio..., op. cit., s. 7.
} 
twierdzącego, że „podstawowym celem nauki jest uwolnienie człowieka z więzów natury i konieczności. Środkiem do tego celu powinien być - zamiast teorii - właśnie eksperyment, bo jedynie on, na drodze doświadczenia, umożliwia rzeczywiste poznanie świata”. . Na gruncie omawianych przeze mnie eksperymentów autor i słuchacz dążą raczej do poznania sztuki, a uwolnienie z więzów dotyczyć może artystę, który w ramach sztuki eksperymentalnej może poruszać się suobodnie, nie bacząc na obowiązujące normy, wyznaczniki czy dotychczasowe praktyki.

W historii eksperymentów dźwiękowych zdają się dominować dua nurty, jedni twórcy wiązali swoje działania z muzyką, drudzy zaś realizowali formy oparte na słowie (lub jego modyfikacjach) i posługiuali się metodami bliskim tym, które dziś nazywany słuchowiskowymi: dramaturgią, scenariuszem, gestem fonicznym.

Pieruszy z nurtów, który pozwolę sobie określić jako muzyczny, na gruncie polskim jest reprezentowany między innymi przez pracouników Studia Eksperymentalnego Polskiego Radia, gdzie nowatorskie działania były wypadkową praktyk kompozytorskich i realizatorskich. Podstawouym obszarem działań stała się muzyka eksperymentalna, czyli „taka, w której kompozytor nie zna z góry rezultatu swojej pracy. Nie chodzi więc ani o skutek, ani o warsztat, ale o oddzielenie jednego od drugiego - pracy od efektu; o rozdzielenie ich nieprzeuidywalnością, o odebranie twórcy kontroli nad rezultatem swojej pracy i przekazanie go czynnikom trzecim - wykonawcom, przypadkowi czy technologii"7. W tworzenie tego rodzaju muzyki jest upisany aleatoryzm, czyli typ konstrukcji dzieła muzycznego, zakładający, w granicach wyznaczonych przez kompozytora, przypadkowość w realizacji wykonawczej, czynnik losouy jako zasada kompozycyjna ${ }^{8}$. Takie właśnie były prace Eugeniusza Rudnika i innych twórców związanych ze Studiem Eksperymentalnym PR, prace te tak ocenia Michał Libera: „z dzisiejszej perspektyuy nagrania Studia [Studia Eksperymentalnego Polskiego Radia - przyp. N.K.] mogą wydawać się wręcz podręcznikowo eksperymentalne. Pozbawione przejrzystej narracji, nawet jeśli krótkie, to zuykle za długie, pełne kontrastów i brzmień à la Ministerstwo Dziunych Dźwięków”. . Libera przywołuje również terminologię Bogusława Schaeffera, który w naturę eksperymentu wpisywał róunież jego poliwersjonalność, możliwość wielokrotnego doświadczenia utworu w wielu jego wersjach.

Realizacje drugiego nurtu eksperymentatorów, który to określam jako nurt słowno-narracyjny, częściej zawierały słowo mówione, operowały planami akustycznymi i stanowiły próbę przedstawienia określonego zamysłu za pomocą dramaturgii dźwięków, gestów fonicznych i zabiegów montażouych, które do dziś są charakterystyczne dla wszystkich radiowych dzieł eksperymentalnych. W tym nurcie została stworzona, uspomniana już przeze mnie, realizacja Wochenende. Jest to dźwiękowy obraz

\footnotetext{
${ }^{6}$ M. Roszkouka, B. Świątkouska, Wstęp, Studio Eksperyment. Zbiór tekstów, Fundacja Bęc Zmiana, Warszawa 2013, s. 7.

${ }^{7}$ M. Libera, Tu się nie..., op. cit., s. 55.

${ }^{8}$ W. Kopaliński, Aleatoryzm, Stownik wyrazów obcych i zwrotów obcojęzycznych, Oficyna Wydawnicza Rytm, Warszawa 2007, s. 23.

${ }_{9}$ M. Libera, Tu się nie eksperymentuje. Tu się po prostu pracuje [w:] Studio Eksperyment..., op. cit., s. 55.
} 
miejskiej przestrzeni Berlina podczas weekendu. Pierwowzorem był film składający się z kilkunastu miejskich scenek Berlin: Die Sinfonie der Großstadt poustały u 1927, po stworzeniu którego Ruttmann postanowił odtworzyć film w wersji radiowej. Program trwa 11 minut, jest kolażem dźwięków, głosów i muzyki; łącznie użyto 228 różnych fragmentów dźwiękouych, niektóre z nich były nagrane u studiu, większość jednak w terenie. Nagranie trwające 11 minut zawierało rytm miejskiego życia zebrany u ciągu dwóch dni. Miejska panorama stawia miasto w roli bohatera audycji w dźwiękowym dialogu, jest realizacją $w$ pełni upisującą się $\mathrm{w}$ ramy eksperymentalnych audycji dokumentalno-artystycznych.

Innym przykładem jest radiowa uersja Wyzwolenie Prometeusza Heinera Goebbelsa. Obok kompozycji muzycznej istotna jest również struktura dramaturgiczna i narracyjna. Autor wykorzystał również tzu. ,found footage, to znaczy istniejący już materiał, z którego tworzy nowe dzieło. Kompozycja radiowa nie jest bowiem napisana i wykonana, ale reżyserowana [...], uszystkie elementy są równie ważne, tkanka dramatyczna czy słowna nie dominuje nad strukturą muzyczną - i na odurót”10. Ta równowaga pomiędzy komponentami muzycznymi i pozamuzycznymi uprowadza audycję na grunt realizacji słowno-muzycznych, które - w zależności od innych komponentów - mogą być postrzegane jako eksperymentalne $w$ duchu nurtu słowno-narracyjnego.

Istotą eksperymentu jest jego unikalność na tle innych realizacji osadzonych w podobnym kontekście, jak piszą dalej Roszkouska i Świątkouska „sztuka przywiązana jest więc do wizji eksperymentu rozumianego jako jednostkowe bądź kolektywne przeżycie niepoutarzalnego wydarzenia" ${ }^{\prime 1}$. Zagrożeniem dla postrzegania takich praktyk może być konotacja eksperymentu z próbą, nieoczekiwanym - i niekoniecznie satysfakcjonującym - efektem. Na taki aspekt zwraca uwagę Józef Robakouski: „ponieważ eksperyment stanowi fazę prób, która nie musi być aktem artystycznym. Jest procesem twórczym, niekoniecznie spełnionym" ${ }^{12}$, dlatego też nie postrzegał nigdy swojej pracy jako procesu eksperymentowania: „w Warsztacie Formy Filmowej nie chcieliśmy robić żadnych eksperymentów, chcieliśmy raczej stwarzać fakty artystyczne, które by były ostatecznymi modelami”" ${ }^{13}$. Opozycja eksperyment - fakt artystyczny hierarchizuje myślenie o sztuce, stawiając ten pierwszy niżej, zrównując go z procesem twórczym, próbą. Hipotezą tego tekstu jest stanowisko przeciwne, eksperyment jako gatunek, forma ostateczna i wartościowa artystycznie. Aby jednak móc dowieźć jej prawdziwości, należy prześledzić pozostałe próby definiowania eksperymentu audialnego, które podejmują temat niezuykle różnorodnie. Jednym z ciekawych głosów w tej kwestii jest zdanie Libery, który zauważa zmianę w pojmowaniu tego typu audycji: „z pewnością zaś [dawniej] określenia tego [eksperymentu - przyp. N.K.] nie używało się

${ }^{10}$ L. Jiřička, Zdobywcy scen akustycznych. Od radioartu do teatru muzycznego: Goebbels, Neuwirth, Ammer, Oehring, Instytut Teatralny im. Zbigniewa Raszeuskiego, Warszawa 2017, s. $12-13$.

${ }^{11}$ Ibidem.

12 J. Robakouski, cyt. za: A. Gruszczyński, Całkowicie stracić kontrolę. Z Józefem Robakowskim rozmawia Arek Gruszczyński [w:] Studio..., op. cit., s. 44.

${ }^{13}$ Ibidem. 
z taką dezynuolturą jak dzisiaj, kiedy eksperymentalne jest uszystko to, co nie mieści się w ramówce radia publicznego w godzinach 6:00-22:00, czyli innymi słowy to, co nie mieści się w dobrze ugruntowanym kanonie"14. Jest to głos o tyle dla mnie istotny, że w dalszej części tego tekstu chciałabym podjąć próbę określenia wyznaczników gatunkouych eksperymentu, co uważam za konieczne, jeśli eksperyment miałby stać się przedmiotem analizy i obiektem badań medioznawczych jako autonomiczna forma radiowa, nie zaś hybryda megagatunkowa.

Definiowanie eksperymentu jako działań spoza głównego nurtu nie jest nowością, podobnie odbierano literaturę eksperymentalną, Raymond Federman tak opisuje postrzeganie prozy eksperymentalnej i proces jej klasyfikacji: „Wszystko, co nie mieści się w kategorii „prozy sukcesu” (komercyjnego rzecz jasna) albo nie jest tym, co Jean Paul Sartre nazywał „literaturą pożyuną”, uszystko, co jest oceniane jako „nie dla czytelników”, zostaje natychmiast zesłane w rejony eksperymentu - w miejsce bezpieczne i jałowe" ${ }^{15}$. Innowacyjność dzieł eksperymentalnych może budzić w odbiorcach niepewność, percepcja „nowego” jest bowiem pochodną zrozumienia „poprzedniego”. Jak podaje Schaeffer, z analogiczną sytuacją mamy do czynienia podczas odbioru nowej muzyki: „muzykę uspółczesną widzimy przez pryzmat muzyki dawnej, przez pryzmat dawnych (a właściwie dziś nieużytecznych czy zgoła szkodliwych) nawyków słuchowych, przez nienowe też pojmowanie uyrazu muzyki. Nowa muzyka oglądana i słuchana, a co więcej - wartościowana na podstawie tych zużytych doświadczeń, będzie zausze trudna, niedostępna, abstrakcyjna, niemająca nic uspólnego z «prawdziwą» muzyką, a może zgoła niedobra, jak to stwierdzają z reguły autorzy myśli o kryzysie sztuki”" ${ }^{16}$. Obok wspomnianej już opozycji próba - fakt artystyczny, również opozycja nowe - stare czy też znane - nieznane staje się przestrzenią, w ramach której zostaje umieszczany eksperyment. Te dwie pary przeciwieństu, cztery zmienne stają się punktami odniesienia wielu definicji form eksperymentalnych, wzajemnie upływając na dynamikę i charakter dzieła.

Eksperyment audialny jest formą radiową, która jest bezpośrednim przełożeniem wizji autora na język dźwięków. Proces twórczy zakłada korzystanie ze wszelkich narzędzi i metod, uszystkiego, co słyszalne, ciszy, kompozycji muzycznych i narzędzi dramaturgiczno-narracyjnych. Istotnymi elementami eksperymentu fonicznego są unikalne zabiegi montażowe i efekty dźwiękowe, autoteliczność przekazu i nawiązania do innych tekstów kultury. Jako dzieło sztuki, prymarną funkcją realizowaną przez tego typu audycje jest funkcja estetyczna. Eksperyment audialny może być adaptacją wcześniej istniejących tekstów kultury lub poustać na podstawie oryginalnego scenariusza, może zawierać kreacje aktorskie rozwijane i rozbudowane partie słowno-narracyjne lub przeciunie - bazować na dygresjach i fragmentaryczności.

\footnotetext{
${ }^{14}$ M. Libera, Tu się nie..., op. cit., s. 55.

${ }^{15}$ R. Federman, Surfikcja - cztery propozycje w formie wstępu [w:] Nowa proza amerykańska. Szkice krytyczne, Czytelnik, Warszawa 1983, s. 422.

${ }^{16}$ B. Schaeffer, W poszukiwaniu muzyki absolutnej [w:] Horyzonty muzyki, red. J. Patkouski, A. Skrzyńska, Polskie Wydawnictuo Muzyczne, Kraków 1970, s. 40.
} 
Allen S. Weiss tak opisuje eksperymentalną audycję Pressures of the Unspeakable Gregory'ego Whiteheada: „To uwertura charakteryzująca się elizją, fragmentacją, wynaturzeniem, dezintegracją, przebitkami, utrąceniami, wielościeżkowymi kompilacjami. To dzieło, które odtwarza dyskurs radiouy za pomocą skrajności. Dlatego też każda próba nadania sensu byłaby zdradą" ${ }^{17}$. Dezintegracja i związana z nią elizja zmieniająca bieg audycji poprzez pomięcie poutarzalnych partii, wielościeżkowość, odniesienia do innych tekstów kultury czy pojęć, nowatorski sposób montażu i narracji są elementami, które sprawiają, że audycja może być traktowana jako eksperymentalna. Najistotniejszą cechą radiowego programu eksperymentalnego zdaje się poszukiwanie nowych form, które korespondują z innymi dziedzinami sztuki lub przesuwają jej dotychczasowe granice.

\section{Estetyka form eksperymentalnych}

Jan Mukařovský podaje, że „każdy przedmiot i każdy proces [...] mogą się stać nosicielami funkcji estetycznej”"18. Audycje eksperymentalne, jak również - choć w mniejszym stopniu - eksperymentalne features ${ }^{19}$, są zorientowane na realizację funkcji estetycznej. Chociaż Mukařovský tuierdzi, że „nie ma trwałej granicy między sferą estetyczną i pozaestetyczną" ${ }^{20}$, to ich proporcje, szczególnie w artystycznych gatunkach radiouych, są zmienne, a same realizacje związane silniej z jedną z nich. Features eksperymentalne ze uzględu na silne związki z dziennikarstwem, a dokładniej z reportażem radiouym, nie odrzucają elementów poznawczych, są one równie istotne jak elementy estetyczne i wizja artystyczna. Podobnie jak w przywołanych przez Jana Mukařovský'ego biografii powieściowej czy eseju, tak u feature występuje „wahanie pomiędzy poezją a komunikatem"21.

W eksperymencie audialnym funkcja estetyczna jest dominująca, jako że „w sztuce funkcja estetyczna jest funkcją dominującą, podczas gdy poza sztuką - jeśli jest obecna ma charakter drugorzędny"22, a nie ma wątpliwości, że eksperymenty audialne są dziełami sztuki. „Celem funkcji estetycznej jest spowodowanie estetycznego zadowolenia”23, jednak sposób jego osiągnięcia w audycjach eksperymentalnych nie zausze wiąże się z środkami, które same w sobie są „miłe dla ucha”, montaż róunież nie zausze pozostaje niezauważalny. Hałas, pisk, modyfikacje głosu czy urwane w procesie montażu dźwięki wykraczają poza estetyczne ramy przyjęte w konwencjonalnych audycjach radiouych. Są to tuorzywa, które poza dziełem byłyby odebrane negatyunie. Takimi nagraniami są produkcje Whiteheada znajdujące się na albumie składającym się z razogramów (połączenie słów: razor (skalpel) i program), a zatytułowanym Disorder Speech z 1984.

\footnotetext{
17 A. Weiss, Phantasmic Radio, Duke University Press Books, Durham 1995, s. 76.

18 J. Mukařovský, Estetyczna funkcja, norma i wartość jako fakty społeczne [w:] Wśród znaków $i$ struktur, Państwowy Instytut Wydawniczy, Warszawa 1970, s. 47.

${ }^{19}$ Feature to radioury reportaż artystyczny.

20 J. Mukařovský, Estetyczna funkcja..., op. cit., s. 47.

${ }^{21}$ Ibidem, s. 54.

${ }^{22}$ Ibidem.

${ }^{23}$ Ibidem, s. 71.
} 
Eva, can I stab bats in a cave to jednominutowe nagranie złożone z kilkunastokrotnego poutórzenia tytułu. Whitehead mówi o nim: „To było całkiem zabawne, gdy w studiu uczyłem się replikować taśmy odtwarzane od tyłu”24. Pierusza była chęć stworzenia nagrania, nie zaś chęć opowiedzenia historii, co odróżnia te realizacje od feature eksperymentalnego. Whitehead mówił o razogramach, że bawił się, tnąc taśmy, improwizował, eksperymentował z manualną edycją taśm dźwiękouych.

Radiowa sztuka eksperymentalna, co jest wpisane w jej naturę, przekracza owe normy, zmienia je. Sztuka ta „naruszenie normy estetycznej stosuje jako jeden z głóunych środków oddziałyuania”25. Eksperyment nie wyrzeka się żadnych dźwięków, narzędzi czy metod, również tych, które pouszechnie można umieścić u kategorii „brzydoty”, którą za Mukařovským rozumiem jako pojęcie szersze od „braku gustu”: „to, co odczuwamy jako niezgodne z normą estetyczną, jest dla nas brzydkie"26. Eksperymentalne formy nie odrzucają zatem praktyk antyestetycznych, twórcy decydują się na wywołanie u odbiorcy „estetycznej dezaprobaty jako części składowej artystycznego efektu”27.

Realizacją z gatunku feature w odmianie eksperymentalnej, która upisuje się w ten sposób tworzenia, jest audycja Gregorego Whiteheada On the Shore Dimly Seen. Audycja porusza temat tortur bezdotykowych stosowanych w Guantanamo na aresztowanym o numerze 063.

Podstawą do stworzenia opowieści był tajny protokół przesłuchania aresztowanego 063, Mohammeda al Qahtaniego, który został ujauniony przez magazyn „Time”. Whitehead był również odpowiedzialny za montaż i kompozycję dokumentu, jego reżyserię i partie wokalne. Piosenkarka Gelsey Bell w On the Shore... wykonuje improwizacje muzyczne, a aktorka Anne Undeland pełni rolę narratora.

Troje twórców wykreowało trójwarstwową konstrukcję. Pierusza płaszczyzna to wokalne improwizacje Bell, „które określają «scenerię» tego niewidzialnego filmu, nie naturalistycznie czy opisowo, ale czysto asocjacyjnie i muzycznie"28. Druga z płaszczyzn to narracja, Gotz Naleppa opisuje fragmenty wypowiadane przez aktorkę jako fakty, pozbawione emocji i komentarza informacje dotyczące technik torturowania w Guantanamo ${ }^{29}$. Gregory Whitehead śpiewający, czy może melorecytujący, słowa protokołu aresztowanego 063 i jednego z agentów odpowiedzialnego za przesłuchanie stanowi trzecią warstuę $e^{30}$; protokoły stały się pewnego rodzaju librettem ${ }^{31}$. Jednak opis tortur wynikający z partii narracyjnych nie jest jedną ich reprezentacją $\mathrm{w}$ audycji.

${ }^{24}$ Opis audycji, http://gregorywhitehead.net/2012/07/28/disorder-speech/ (dostęp: 20.10.2018).

${ }^{25}$ Ibidem, s. 75.

${ }^{26}$ Ibidem, s. 76.

${ }^{27}$ Ibidem, s. 77.

${ }^{28}$ G. Naleppa, On The Shore Dimly Seen: Review, „RadioDoc Rewiev” 2015, nr 2(2), s. 1.

${ }^{29}$ Ibidem.

${ }^{30}$ Ibidem.

${ }^{31}$ G. Whitehead, Earworms + Radio Voices: In Conversation with Gregory Whitehead, http:// uww.earlid.org/posts/earworms-radio-voices-in-conversation-with-gregory-whitehead/ (dostęp: 19.03.2017). 
Wokalne improwizacje Bell wchodzą na uysokie tony, które mogą być nieprzyjemne dla słuchacza, a poutarzające się w tle dźwięki nakręcania zegara, pogłosy i echa mogą wprawiać w zaniepokojenie i stwarzać mroczną atmosferę.

\section{Struktura eksperymentów radiowych}

Eksperymenty audialne nurtu słowno-narracyjnego w swej formie mogą przypominać słuchowiska bądź reportaże radiowe. Pozostają jednak niezależne od zasad kompozycji, funkcji poznawczych czy informacyjnych, często jedynie nieznacznie do nich nawiązują. Eksperymenty radiowe, jako audycje pozwalające twórcy na dużą swobodę artystyczną, odznaczają się dużym zróżnicowaniem wewnątrzgatunkouym i wieloma zmiennymi strukturalnymi. Chciałabym jednak, w formie przyczynkouej, podjąć temat struktury w odniesieniu do tego typu realizacji. Mukařovský opisał strukturę jako „całość, która określa sobą charakter swoich elementów [...] Słowem: hierarchia, wzajemna podrzędność i nadrzędność składników. [...] chwiejna równowaga sił stale przemieszczających się" ${ }^{\prime 2}$. Istotny jest dla badacza relacyjny charakter poszczególnych składouych struktury: relacje pomiędzy elementami i ich dynamika, która ma bezpośrednie przełożenie na efekt końcowy. Do wzajemnie dynamizujących się elementów można zaliczyć: tuorzywa głosowe, muzykę, efekty dźwiękowe, montaż i wykorzystanie technologii, ciszę, gesty foniczne, metafory dźwiękoue.

Struktura jako zbiór elementów w dziele, relacji między nimi, jak i ich relacja z całością, stają się konstruktem, którego badanie - zgodnie z założeniami myśli strukturalistycznej - powinno obejmować również upływy, jakim poddaje się dane dzieło sztuki. Struktura jako pojęcie obejmujące zaróuno formę, jak i treść dzieła wprowadza odbiorę na pole interpretacji całościowej, równomiernie zostają rozłożone znaki i znaczenia. René Wellek i Austin Warren twierdzili, że „zamiast przeciustawiać «formę» i «treść», użyuamy pojęcia materii oraz «formy» jako tego, co estetycznie organizuje «materię»" ${ }^{33}$. Holistyczne pojmowanie eksperymentu sprawia, że może on być traktowany i rozumiany jako doświadczenie estetyczne, co uwypukla nadrzędną funkcję tego typu realizacji - funkcję estetyczną.

Zrównanie formy z treścią sprawia, że również wzorzec gatunkowy nie zawiera elementów ich rozróżniających. Konstrukcja audialnych dzieł eksperymentalnych jest formą ostateczną i jako całość powinna zostawać poddawana analizie czy interpretacji.

Maria Wojtak u opisie metodologii badawczej koniecznej do analizy gatunków dziennikarskich wyszczególniła cztery aspekty wzorca gatunkowego: aspekt strukturalny, aspekt pragmatyczny, aspekt poznawczy i aspekt stylistyczny ${ }^{34}$. Rozpatrywanie eksperymentu jako gatunku wymaga ustalenia wzorca gatunkowego, który będzie

\footnotetext{
32 J. Mukařovský, Wśród znaków i struktur, Państwowy Instytut Wydauniczy, Warszawa 1970, s. 47.

${ }^{33}$ R. Wellek, A. Waren, Teoria literatury, PWN, Warszawa 1974, s. 329-330.

${ }^{34}$ M. Wojtak, Gatunki prasowe, Wydawnictwo Uniwersytetu Marii Curie-Skłodouskiej, Lublin 2004, s. 16.
} 
pełnić rolę punktu odniesienia w przypadku kwalifikowania audycji jako odpowiednich gatunków radia artystycznego. W odniesieniu do eksperymentu jako gatunku rozumiem wymienione wcześniej komponenty następująco:

1. Aspekt strukturalny - stanowi kompozycję dzieła wraz z poszczególnymi scenami, elementami i tworzywami głosowymi. Do kompozycyjnych cech charakterystycznych zaliczam poliwersjonalność lub wewnętrzne zróżnicowanie elementóu dzieła, jego dezintegrację, elizję czy pozorną nieprzystawalność poszczególnych elementów i ich relację z całością kompozycji;

2. Aspekt pragmatyczny jest reprezentacją celu komunikatu, sytuacji odbiorcy i nadaucy oraz potencjału illokucyjego, dzieło sztuki jest komunikatem skierowanym od nadawcy do odbiorcy. Nadrzędnym celem jest przekazanie artystycznej wizji nadaucy i osiągnięcie estetycznej satysfakcji u odbiorcy, niezależnie od - róunież antyestetycznych - środków. Przekraczanie norm estetycznych i przesuwanie granic sztuki jest charakterystyczne dla dzieł eksperymentalnych;

3. Aspekt poznawczy to temat audycji i sposób jego przedstawienia, aksjologia, perspektywa. Eksperymenty radiowe cechuje pełna dowolność tematyczna, również kontrowersyjna, metaforyczna czy surrealistyczna. Charakteryzuje je autorski punkt widzenia, liczne nawiązania do innych tekstów kultury, form, nurtów i gatunków oraz unikalność wykorzystanych tworzyw i/lub metod;

4. Aspekt stylistyczny jest związany z użytymi środkami dźwiękouymi: tworzywami głosouymi, kuchnią akustyczną, muzyką, świadomym użyciem ciszy, zasoby dźuiękowe są nieograniczone, dopuszcza się użycie antyestetycznych środków wyrazu. Zniesiony zostaje podział na formę i treść, forma zróunana jest z treścią, oba te komponenty są równoważne i nie powinny być interpretowane czy analizowane osobno.

Wzorzec gatunkowy stanowi pewien stały zespół cech, ramę, w której umieszczone mogą zostać audycje określane jako eksperymentalne. Jednak pamiętać należy o jego wariacyjności i unikalności audialnych dzieł sztuki. Jak pisze Wojtak: „Wzorca gatunkowego nie traktuję zatem jako jakości stałej (trwałej) ani miary stopnia doskonałości jednostkowych wykonań” ${ }^{5}$. Uwaga dotycząca miary stopnia doskonałości zdaje się szczególnie ważna w kontekście działań artystycznych i eksperymentalnych. Podstawa, jaką stanowi wzorzec gatunkowy, ma ukazywać jedynie perspektywę genologiczną, która może towarzyszyć badaniom i analizom audycji.

\section{Uwagi końcowe}

W naturę eksperymentu na stałe wpisane jest poszukiwanie nouych form, różnorodność realizacji, ciągle przesuwanie granic sztuki i odnajdywanie nawiązań do innych tekstów kultury. Mimo ukazanej we wzorcu gatunkowym eksperymentu radiowego innowacyjności i nieprzewidywalności poszczególne reprezentacje mają cechy uspólne,

35 Ibidem, s. 18. 
które ów wzorzec budują. Audycje spoza klasycznego kanonu gatunków radiowych miały upływ na ich rozwój, szczególnie w pierwszych latach istnienia radia. Słowny nurt eksperymentów audialnych bezpośrednio wpłynął na rozwój słuchowiska, feature'a i reportażu radiowego, jednak każda innowacja pośrednio oddziałuje na wszystkie późniejsze realizacje. Efekt końcowy bywa nieznany dla autora w procesie twórczym, eksperymentalny jest proces i efekt, metody i treści. Nie oznacza to jednak przypadkowości rozumianej jako błądzenia czy nieświadomości użytych technik. Eksperyment radiowy jako gatunek jest faktem artystycznym, nie zaś procesem, nie każdy bowiem dowolnie skomponowany twór dźwiękowy wpisuje się we wzorzec gatunkowy i jest wartościowy artystycznie.

\section{Bibliografia}

Bray J., Gibbons A., McHale B., Introduction [w:] The Routledge Companionto Experimental Literature, red. J. Bray, A. Gibbons, B. McHale, Routledge, London-New York 2012.

Federman R., Surfikcja - cztery propozycje w formie wstępu [w:] Nowa proza amerykańska. Szkice krytyczne, Czytelnik, Warszawa 1983.

Gruszczyński A., Całkowicie stracić kontrolę. Z Józefem Robakowskim rozmawia Arek Gruszczyński [w:] Studio Eksperyment. Zbiór tekstów, Fundacja Bęc Zmiana, Warszawa 2013. Hall M., Radio After Radio: Redefining radio art in the light of new media technology through expanded practice, maszynopis pracy doktorskiej, Londyn 2015.

Helman A., Autotematyzm [w:] Stownik filmu, red. R. Syska, Krakouskie Wydawnictuo Naukoue, Kraków 2010.

Jiřička L., Zdobywcy scen akustycznych. Od radioartu do teatru muzycznego: Goebbels, Neuwirth, Ammer, Oehring, Instytut Teatralny im. Zbigniewa Raszewskiego, Warszawa 2017.

Kopaliński W., Słownik wyrazów obcych i zwrotów obcojęzycznych, Oficyna Wydawnicza Rytm, Warszawa 2007.

Libera M., Tu się nie eksperymentuje. Tu się po prostu pracuje [w:] Studio Eksperyment. Zbiór tekstów, Fundacja Bęc Zmiana, Warszawa 2013.

Mukařovský J., Estetyczna funkcja, norma i wartość jako fakty społeczne [w:] Wśród znaków i struktur, Państwowy Instytut Wydawniczy, Warszawa 1970.

Mukařovský J., Wśród znaków i struktur, Państwowy Instytut Wydawniczy, Warszawa 1970.

Naleppa G., On The Shore Dimly Seen: Review, „RadioDoc Rewiew 2015, nr 2(2).

Roszkouska M., Świątkouska B., Wstęp, Studio Eksperyment. Zbiór tekstów, Fundacja Bęc Zmiana, Warszawa 2013.

Schaeffer B., W poszukiwaniu muzyki absolutnej [w:] Horyzonty muzyki, red. J. Patkouski, A. Skrzyńska, Polskie Wydawnictwo Muzyczne, Kraków 1970.

Weiss A., Phantasmic Radio, Duke University Press Books, Durham 1995.

Wellek R., Waren A., Teoria literatury, przeł. M. Żurouski, PWN, Warszawa 1974.

Wojtak M., Gatunki prasowe, Wydawnictwo Uniwersytetu Marii Curie-Skłodouskiej, Lublin 2004.

\section{Netografia}

Whitehead G., Earworms + Radio Voices: In Conversation with Gregory Whitehead, http:// www.earlid.org/posts/earworms-radio-voices-in-conversation-with-gregory-whitehead/ (dostęp: 19.03.2017). 